Relation of lecithin:sphingomyelin ratio $(L S R)$ to presence of vernix in amniotic fluid

\begin{tabular}{|c|c|c|c|c|}
\hline & \multicolumn{3}{|c|}{ LSR } & \multirow{2}{*}{ Total } \\
\hline & 2 & $2 \cdot 1-3$ & $>3$ & \\
\hline $\begin{array}{l}\text { No vernix seen } \\
\text { Cloudy, with doubtful } \\
\text { presence of vernix }\end{array}$ & $\begin{array}{r}17 \\
0\end{array}$ & $\begin{array}{r}12 \\
4\end{array}$ & $\begin{array}{l}4 \\
8\end{array}$ & $\begin{array}{l}33 \\
12\end{array}$ \\
\hline Vernix definitely present & 0 & 5 & 29 & 34 \\
\hline Total & 17 & 21 & 41 & 79 \\
\hline
\end{tabular}

$\chi^{2}=34 \cdot 87 ; \mathrm{DF}=4 ; \mathrm{P}<0 \cdot 001 ;$ contingency coefficient $=$
$=$

LSR is sometimes found in clear amniotic fluid, no immature LSR $(\leqslant 2)$ was seen whenever vernix was present.

Our findings suggest that amnioscopy might be used to assess fetal maturity before induction of labour. Induction can proceed if vernix is seen in the amniotic fluid and amniocentesis for the measurement of amniotic fluid LSR need be performed only when no vernix is seen.

JOHN M MCLAUGHLAN Allan M Z Chang

Department of Obstetrics and

Gynaecology,

Mater Misericordiae Mothers'

Hospital,

South Brisbanc

Medical services for new towns

SIR,-Scrutator (12 November, p 1297) rightly points out the difficulties faced by the Northamptonshire Area Health Authority in providing services for the new towns of Northampton and Milton Keynes. He has, however, made an error in believing Milton Keynes to be in Northamptonshire, for it is in Buckinghamshire and the majority of the burden of providing health services rests with the Buckinghamshire Area Health Authority.

The population of Milton Keynes is now 80000 and increasing by 8000 to 10000 persons a year. As Milton Keynes has no acute hospital patients requiring admission to hospital must travel 20 miles north to Northampton or 20 miles south to Aylesbury, and approximately half go in each direction. This need to travel 20 miles for acute hospital services does occur elsewhere, but only in on or two sparsely populated areas (for example, mid-Wales). In Aylesbury itself acute beds, as well as spinal and geriatric beds, are being reduced in number, and one hospital is recommended for closure in order to reduce expenditure to the level of our income. Although planning of a 250-bed first-phase district general hospital for Milton Keynes is under way, building will not start until 1980 and it is unlikely to open before 1985 , by which time the population of 150000 or so will still be insufficiently provided with hospital facilities. To attempt to reduce the problem the Buckinghamshire AHA has provided a good level of primary support care in association with general practice, but it is not currently possible to increase further the level of district nursing or health visiting staff to keep pace with population growth.

The Oxford Region, in which Buckinghamshire and Northamptonshire fall, is, by RAWP data, overfunded. Yet currently the formula uses a population base two years out of date and makes no allowance for the problems of providing services in a "green fields" site. To find $£ 6 \mathrm{~m}$ to build a small district general hospital out $r f$ an annual capital budget of $£ 9 \mathrm{~m}$ is a daunting task for the Regional Health Authority. No less daunting is the task of finding $£ 2 \mathrm{~m}$ per year to run it.

David Miles

Aylesbury and Milton Keynes

Health District

Milton Keynes, Bucks

Miles, D P B, and Yule, I G, Health Trends, 1977,
9, 63 .

\section{Emergency in emergency departments}

Sir,-Mr C C Slack's letter (19 November, p 1359) about staffing in accident and emergency departments certainly described the problems we have in Hull very well. If anything, our situation is deteriorating. I am sure he is right that changes in pay structure for senior house officers in accident and emergency departments should be made to make the posts more attractive.

$\mathrm{Mr}$ Slack does mention another change which I think could stabilise the ever-moving staff of many departments. Of all specialties, accident and emergency needs permanen doctors with knowledge of local circumstances and geography. The appointment of consultants has gone some way towards providing this, but I would submit that further appointments of permanent medical staff should be made at a non-consultant grade-as Mr Slack says, "a career grade for hospital doctors" not necessarily with specialist degrees.

During my surgical training I greatly enjoyed my six months in accident and emergency. Apparently I am unusual, but I know there are others. My training was interrupted by family circumstances and I count myself very lucky to work in the department in Hull. At present this can only be as clinical assistan with a maximum of nine sessions per week. There is no career prospect and there is, at least on paper, the insecurity of annual renewal. Clinical assistant sessions were never intended to provide a doctor with his principal employment and I would certainly prefer to work on a whole-time basis. Am I right in thinking that there are other doctors in my anomalous situation in other parts of the country?

I know the medical assistant grade is not favoured now, but if the experience of Tynemouth and Hull is indeed shared by accident and emergency departments all over the country a stable element of permanent, nontraining, whole-time doctors may well be critical in keeping their doors open.

JONATHAN MARROW

Accident and Emergency

Department

Hull Royal Infirmary

\section{Removal expenses of clinical academic} staff

SIR,-An inference has been drawn that the choice of King's College and Southampton University as targets for an attempt to improve the removal expenses paid to clinical academic staff (12 November, p 1300) was governed by the level of removal expenses paid by these institutions. Both are close to the average in fact and were selected for an entirely pragmatic reason: they are convenient for negotiation.

We have received no positive response from
Southampton, but I have learnt recently that King's College have doubled spontaneously their removal expenses payable to clinical academic staff.

E GREY-TURNER

London WC Secretary, BMA

\section{General practice premises}

SIR,-In the article on general practice premises (26 November, p 1432) it is stated in the fourth paragraph, headed "Owned premises and notional rent," that premises used for residential purposes do not attract rent.

My receptionist is resident in the flat over the surgery. This is one of the conditions of her employment. Surely I am entitled to rent for the part of the premises in which she resides.

Cases in which the practitioner is the resident are different from those in which ancillary staff are resident.

T WHITE

Croydon, Surrey

${ }_{*}^{*}$ Dr White is right. But the receptionist or other ancillary staff member) must be responsible for answering emergency calls from patients after surgery hours if the residence is to be included in the rent and rates scheme.-ED, BMF.

\section{Decline of visiting}

SIR,-Surely Dr A E Loden (19 November, p 1359) writes with pen in cheek. His "ultimate" case so lacks background information as to be but an emotive issue. Could he really be harking back to the "good old days" or is he, as a member of the General Medical Services Committee, hoping to evince a roar of derisory cat calls?

Many would note not only a decline in visiting but a decline to visit, for, if the home attendance has an undoubted social value to be set against its dubious therapeutic need, it is becoming more and more beyond the purse of an average general practitioner.

Maybe the country is bemused by the inevitable fall in standards that inflation brings, but "visiting" is a way of life rather than a need, and, like the old dentist's bag of humbugs, more inclined to produce work than results.

Swindon, Wilts

J Hywel Rees

SIR,-Dr D J Pereira Gray, who gave the annual James Mackenzie lecture to the Royal College of General Practitioners recently, is quoted in the medical press as saying that there has been a steady decline in the number of home visits recently and that the general practitioner now does an average of less than one visit a day. If the reporting is accurate the implication of this is that many, if not most, GPs are doing no visits at all. This I cannot accept.

From what source do the figures come which make an intelligent man make such a statement on a public platform? It is statements like this which irritate the profession, confuse the public, and give comfort to the Government of the day in their efforts to bring the profession to heel.

Sowerby Bridge, W Yorks 